\title{
Morphological response of the saltmarsh habitats of the Guadiana estuary due to flow regulation and sea-level rise
}

\author{
D.M.R. Sampath*, T. Boski \\ CIMA- Centro de Investigação Marinha e Ambiental, Universidade do Algarve, Campus de Gambelas, 8005-139 Faro, Portugal
}

\section{A R T I C L E I N F O}

\section{Article history:}

Received 3 March 2016

Received in revised form

3 June 2016

Accepted 16 July 2016

Available online 19 July 2016

\section{Keywords:}

Long-term morphological evolution

Estuary

Saltmarsh

Sea-level rise

Environmental flow

\begin{abstract}
A B S T R A C T
In the context of rapid sea-level rise in the 21st century, the reduction of fluvial sediment supply due to the regulation of river discharge represents a major challenge for the management of estuarine ecosystems. Therefore, the present study aims to assess the cumulative impacts of the reduction of river discharge and projected sea-level rise on the morphological evolution of the Guadiana estuary during the 21st century. The assessment was based on a set of analytical solutions to simplified equations of tidal wave propagation in shallow waters and empirical knowledge of the system. As methods applied to estimate environmental flows do not take into consideration the fluvial discharge required to maintain saltmarsh habitats and the impact of sea-level rise, simulations were carried out for ten cases in terms of base river flow and sea-level rise so as to understand their sensitivity on the deepening of saltmarsh platforms.

Results suggest saltmarsh habitats may not be affected severely in response to lower limit scenarios of sea-level rise and sedimentation. A similar behaviour can be expected even due to the upper limit scenarios until 2050, but with a significant submergence afterwards. In the case of the upper limit scenarios under scrutiny, there was a net erosion of sediment from the estuary. Multiplications of amplitudes of the base flow function by factors $1.5,2$, and 5 result in reduction of the estimated net eroded sediment volume by 25,40 , and $80 \%$, respectively, with respect to the net eroded volume for observed river discharge. The results also indicate that defining the minimum environmental flow as a percentage of dry season flow (as done presently) should be updated to include the full spectrum of natural flows, incorporating temporal variability to better anticipate scenarios of sea-level rise during this century. As permanent submergence of intertidal habitats can be significant after 2050, due to the projected $79 \mathrm{~cm}$ rise of sea-level by the year 2100, a multi-dimensional approach should be adopted to mitigate the consequences of sea-level rise and strong flow regulations on the ecosystem of the Guadiana Estuary.
\end{abstract}

(c) 2016 Elsevier Ltd. All rights reserved.

\section{Introduction}

Estuarine ecosystems-including saltmarshes-provide economic, social, and environmental benefits, including distinctive biodiversity and important ecosystem services such as coastal defence, fishery support, and nutrient cycling (Veiga et al., 2006). Saltmarshes are built on the fine-grained sediment substratum of the intertidal zone and are among the most fragile coastal habitats whose equilibrium depends on a variety of anthropogenic and natural processes (Dijkema, 1987). Saltmarshes are vulnerable to rising sea levels, coastal developments, pollution due to

\footnotetext{
* Corresponding author

E-mail address: rmudiyanselage@ualg.pt (D.M.R. Sampath).
}

urbanization, farming and aquaculture (Boorman et al., 2002), and any decrease in river discharge forced by damming, and intensive irrigation upstream (Wolanski et al., 2006). Since numerous observations have established climate change driven rapid sea-level rise (SLR) with increased ice sheet melting during the 21st century (Paolo et al., 2015; Seo et al., 2015; IPCC, 2014), saltmarshes can be exposed to increased hydroperiod, erosion, and long-term submergence (French, 2006).

Saltmarshes develop naturally when intertidal mud flats accumulate fine sediments to a level at which pioneer saltmarsh plant species can colonize, if conditions are suitable for their germination and establishment (Boorman et al., 2002). Development of saltmarshes and their long-term survival will therefore depend on the hydroperiod, which is ultimately controlled by the rising sea level (Day et al., 2000) and both allochthonous and autochthonous 
sedimentation (French, 2006). In contrast to the Holocene period of high sediment input, which supported a depositional coastal response to SLR, coastal systems such as saltmarshes retreat under future SLR, with reduced river flow and terrestrial sediment input due to increased damming (Plater and Kirby, 2006). In the case of the Guadiana estuary saltmarshes, fine-grained sediment is mainly derived from fluvial sources; thus river discharge is critical for sustaining saltmarsh habitats. Influence of wind waves is insignificant in saltmarshes as waves are typically attenuated by littoral spits or barrier islands (Morales et al., 2006) and vegetation canopy (Möller and Spencer, 2002).

The environment of an estuarine system can be degraded when the system is poorly flushed due to reduced freshwater inflows during periods of drought or flow regulations by dams (Mateus et al., 2008). The discharge of the Guadiana River is regulated by more than 100 dams, including the Alqueva dam, which was completed in 2002 and now forms the largest fresh-water reservoir in Europe (Dias et al., 2004). Low river discharge $\left(<20 \mathrm{~m}^{3} / \mathrm{sec}\right)$ and pulse-like, unseasonal river flows are characteristic of the post-dam phase of the Guadiana River (Wolanski et al., 2006). These dams effectively trap sediments eroded in the catchment instead of being transported to the coastal system. The present area of the saltmarsh habitat is less than the mid-late Holocene period (Boski et al., 2008) when, following the maximum post-glacial transgression, a progressive infilling of the estuarine embayment occurred.

The most widely used strategy to mitigate the negative consequences of river runoff regulations is based on defining environmental flows (EF), which are the minimum water requirements left in a river system-or released into it-for the specific purpose of managing the conditions and functioning of that ecosystem (King et al., 2003). The objective of EF is to mimic components of the river's natural flow variability, including the magnitude, frequency, timing, duration and rate of change, and predictability of flow events (Arthington et al., 2006). The main types of flow-assessment approaches are: (1) hydrological; (2) hydraulic rating; (3) habitat rating; and (4) holistic (Tharme, 2003). The first approach is based on long-term hydrological time-series data and the utilization of a summary of flow statistics-which may or may not be ecologically relevant-to define suitable flows, often for fish habitats (Gopal, 2013). Probably because of the time-scale of the phenomena concerned, no EF assessment methods focus on the fluvial discharge required to maintain saltmarshes and do not consider impacts of SLR.

The adequacy of the approach that determines EF for rivers in Portugal has been challenged (e.g., Galvão et al., 2012; Chícharo et al., 2009). For the Guadiana River, EF is $2 \mathrm{~m}^{3} / \mathrm{sec}$, during the dry season (Wolanski et al., 2006). Thus, the Guadiana estuarine system is likely to be affected by an increased rate of sea level and starved fluvial sediment due to the construction of large dams (Sampath et al., 2015). Therefore, this study is focused on a modelbased assessment of the role of river discharge in maintaining the depth of the intertidal zone where the saltmarshes can thrive. The main objectives of this study are twofold: (1) to simulate the morphological evolution of the Guadiana estuary under the updated (Hunter, 2010) 5\% and 95\% limit time-series of the A1FI SLR scenario (IPCC, 2007) and reduced river discharge due to dams; and (2) to assess the sensitivity of the base flow of the river discharge to morphological evolution, as a preliminary estimation method of the EF within the holistic approach (King et al., 2003).

\section{Study area}

\subsection{Hydrological and hydrodynamic setting}

The Guadiana estuary (Fig. 1) is located along the southwestern border of Portugal and Spain, in a semi-arid region with a Mediterranean climate (Faria et al., 2006). According to Garel et al. (2009), the river inputs that flow into the Guadiana estuary are highly variable; at a seasonal and inter-annual scale, they produce severe droughts and episodic floods in the river basin (Fig. 2a). The monthly river discharge ranged from $<10 \mathrm{~m}^{3} / \mathrm{sec}$ to $4660 \mathrm{~m}^{3} / \mathrm{sec}$ for the period of $1947-2001$, with $50 \%$ of the recorded values were less than $110 \mathrm{~m}^{3} / \mathrm{sec}$ (Garel et al., 2009). The mean river flow measured at Pulo do Lobo (ca. $85 \mathrm{~km}$ upstream from the river mouth) during the summer reached $20-25 \mathrm{~m}^{3} / \mathrm{s}$ during 1997 and 1998 , before closing of the Alqueva Dam, and decreased to below $10 \mathrm{~m}^{3} / \mathrm{sec}$ from 1999 to 2003, during the Alqueva Dam's construction and filling Galvão et al. (2012). Following the dam's completion, summer river flow increased to $10-15 \mathrm{~m}^{3} / \mathrm{s}$ during 2004 and 2005 , reached $20-25 \mathrm{~m}^{3} / \mathrm{s}$ during 2007 and 2008 and declined back below $10 \mathrm{~m}^{3}$ / sec during 2008 and 2009 (Fig. 2b). Currents observed in the estuary result from tides and river flow (Fortunato and Oliveira, 2004) and, because the system has few tidal flats (Fortunato et al., 2002), it is notably flood-dominated. The estuary exhibits a semi-diurnal, meso-tidal regime with a mean range of approximately $2.5 \mathrm{~m}$. The mean neap tidal range is $1.22 \mathrm{~m}$ and the mean spring tidal range is $2.82 \mathrm{~m}$ (Garel et al., 2009), with a maximum spring tidal range of $3.5 \mathrm{~m}$ (Fortunato and Oliveira, 2004). Tidal waves in the estuary generates currents with velocities exceeding $0.5 \mathrm{~m} / \mathrm{s}$ (Morales, 1997).

\subsection{Sediment transportation}

On the Portuguese margin, saltmarshes are sheltered by an ebbtidal delta that drains into the estuarine channel, while the eastern margin is a mosaic of barrier islands and spits separated by extensive saltmarshes that mainly drain to the sea through the Carreras tidal inlet (Morales et al., 2006). According to the overall sediment budget of the Guadiana estuary, estimated bed load and suspended load are about 43.96 and $57.9 \times 10^{4} \mathrm{~m}^{3} / \mathrm{yr}$, respectively (Morales, 1997). The estuary may have trapped approximately $10 \%$ of the total fluvial sediment contribution $\left(0.5-1.5 \times 10^{6} \mathrm{t} / \mathrm{yr}\right)$ to the littoral zone from 1980 to 2000 (Portela, 2006). Sediments transported during an exceptional flood contained higher inorganic fraction and the construction of the Alqueva dam will attenuate these flood events, decreasing the amount of sediment supplied by the river to the coastal zone in the future (Caetano et al., 2006). Under low flow conditions $\left(Q_{R}<50 \mathrm{~m}^{3} / \mathrm{sec}\right)$, the Guadiana Estuary can be considered well-mixed in salinity (Fortunato et al., 2002) and the suspended sediment concentration (SSC) is $10 \mathrm{mg} / \mathrm{L}$ at the mouth and about $100 \mathrm{mg} / \mathrm{L}$ in the middle estuary; where maximum turbidity is observed (Garel et al., 2009). Suspended sediment is predominantly composed of phyllosilicates, represented principally by illite (>50\%), kaolinite, and chlorite (Machado et al., 2007). The fluvial sediments exported from the estuary mix in the proximity of the river mouth with sediments transported by longshore drift (Gonzalez et al., 2004). Tidal currents carry this sediment back into the estuarine system (Boski et al., 2008).

\subsection{Bed sediment types}

Well sorted medium sand (quartz, feldspar, bioclasts, plus lithic components of diverse origin) lies at the lower estuary (Lobo et al., 2004). Only about $7 \mathrm{~km}$ of the channel from the mouth is composed of soft sediment (Garel et al., 2009). Channel bottom sediments are predominantly sands, except in the intertidal zone flanks, which are covered by muds (Fortunato and Oliveira, 2004). Morales et al. (2014) distinguished four types of beds in the lower estuary (Table 1). The distribution of sediment grain size (Fig. 3) within the study area is based on data provided by Boski et al. $(2002,2008)$ 


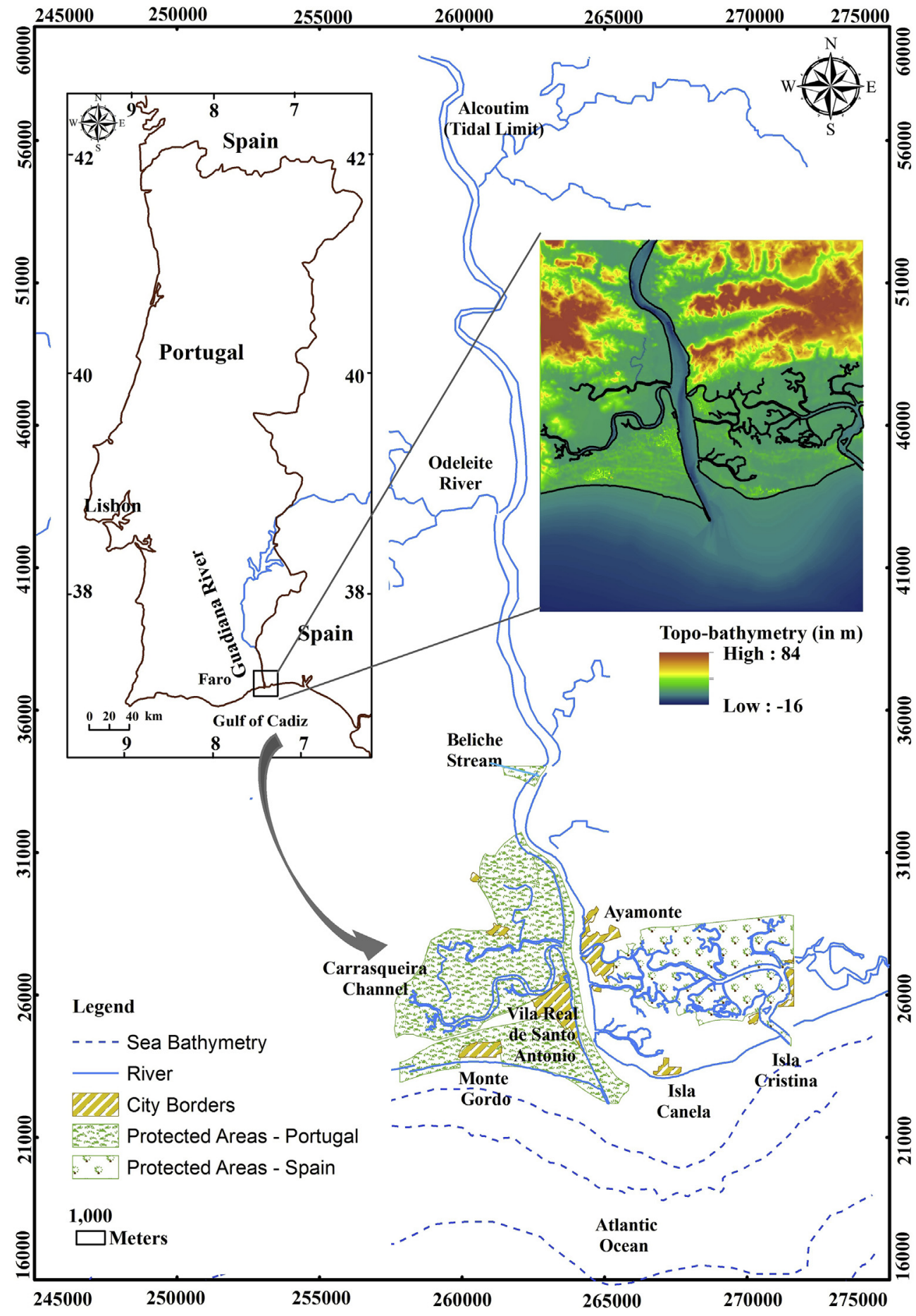

Fig. 1. The Guadiana Estuary and the topo-bathymetry of the lower estuary.

and Morales et al. (2006). However, grain size distribution in the intertidal zone was derived using a limited number of samples.

\section{Methodology}

For the purpose of this study we have chosen an approach based on a hybrid model. This model was developed from a set of morphological expressions derived by Prandle $(2004,2009)$ and supported by empirical knowledge of the system. Sampath et al. (2015) provide comprehensive details of the mathematical basis underlying the long-term model, which was validated in two ways: (1) by comparing the observed present-day bathymetry of the Guadiana River Estuary with the corresponding simulated bathymetries for nine control sections across the estuary, and (2) by applying the age model based on 16 radiocarbon ages obtained from five boreholes in the estuary. The short term, decadal morphological evolution model was validated using bathymetric data from 2000 to 2014 (Sampath, 2016).

The estuarine, sediment surface aggradation model of Allen (1995) can be simplified and the rate of relative elevation change 

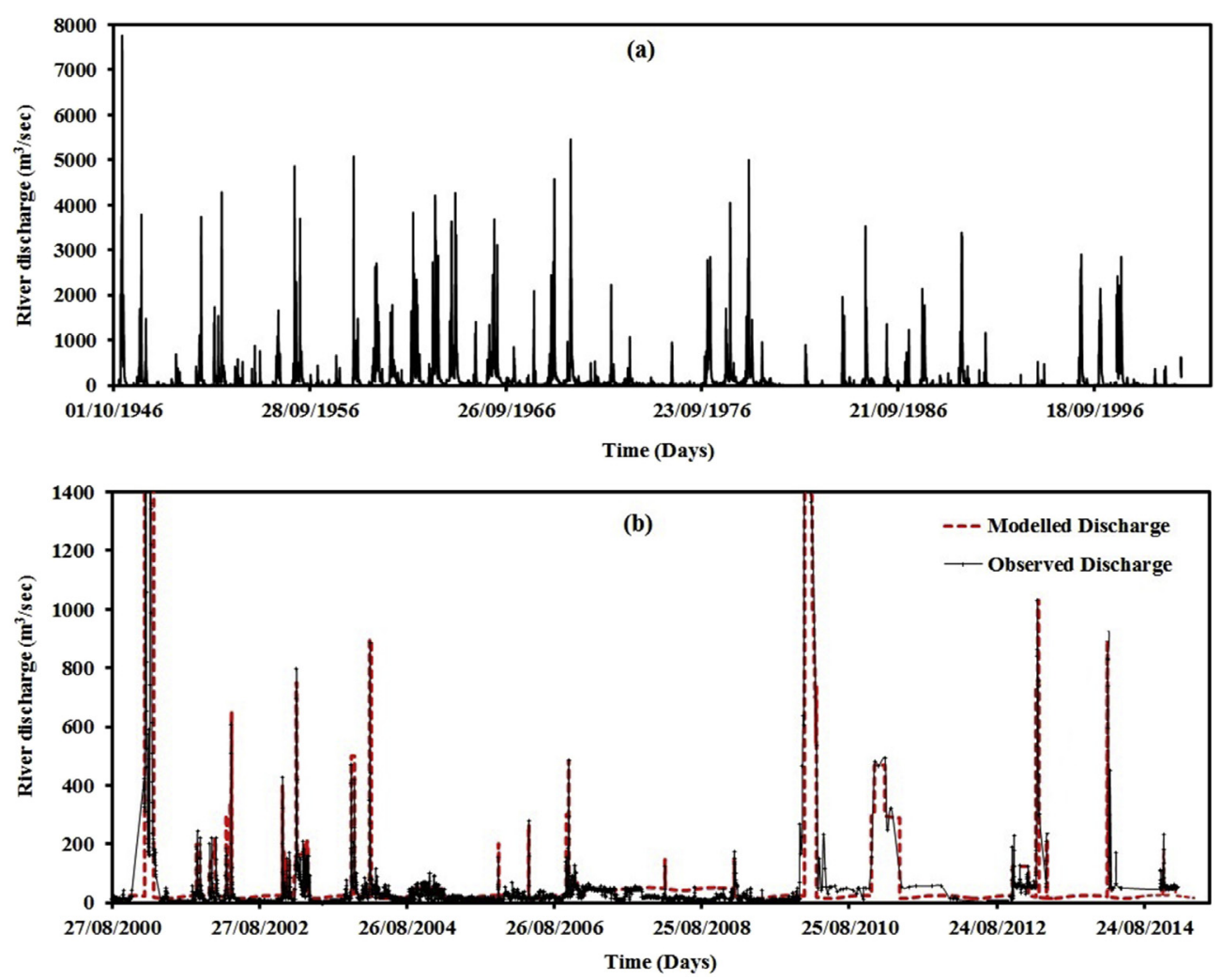

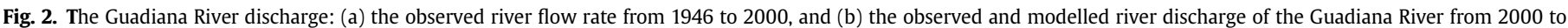
2014 May (Source: http://snirh.inag.pt/).

Table 1

Bed sediment types in the lower estuary (Morales et al., 2014).

\begin{tabular}{|c|c|c|c|}
\hline Type & Distribution & Mean grain types & Characteristics \\
\hline 1 & From mouth to $3 \mathrm{~km}$ & Coarse sand (Primary) medium sand & $\begin{array}{l}\text { Moderate sorting, } \\
\text { Mesokurtic shape } \\
\text { Positive skewness }\end{array}$ \\
\hline 2 & Central channel from 3 to $4 \mathrm{~km}$ & Medium sand (Primary) coarse and fine sands & $\begin{array}{l}\text { Moderate sorting, } \\
\text { Leptokurtic shape } \\
\text { Positive skewness }\end{array}$ \\
\hline 3 & Portuguese margin and in the central channel above $4.5 \mathrm{~km}$ from the mouth & Very fine sediment & $\begin{array}{l}\text { Extremely poor sorting } \\
\text { Platykurtic shape } \\
\text { Negative skewness }\end{array}$ \\
\hline
\end{tabular}

$(\mathrm{dZ} / \mathrm{dt})$ at a given point of the estuary bed represented in terms of mineral sedimentation rate $\left(\mathrm{dS}_{\mathrm{Min}} / \mathrm{dt}\right)$, erosion rate $(\mathrm{dE} / \mathrm{dt})$ and SLR rate $\left(\mathrm{dM}_{\mathrm{MSL}} / \mathrm{dt}\right)$; (Eq. (1)).

$\frac{\mathrm{dZ}}{\mathrm{dt}}=\frac{\mathrm{dS}_{\mathrm{Min}}}{\mathrm{dt}}-\frac{\mathrm{dM}_{\mathrm{MSL}}}{\mathrm{dt}}-\frac{\mathrm{dE}}{\mathrm{dt}}$

This simplified expression is fully applicable to the Guadiana Estuary case, where deep subsidence is found to be negligible (Lobo et al., 2003) and where sediment organic fraction (Gonzalez Vila et al., 2003) and auto-compaction (Santos and Boski, 2000) are also insignificant for the purpose of long-term simulation of morphological evolution (Sampath et al., 2015). Elevation change $(\Delta \mathrm{Z})$ at a given initial depth (h) over $\Delta \mathrm{t}$ time-step can be derived by integrating mineral deposition and erosion over each tidal cycle over several years with $m$ tidal cycles, where $\alpha=1$ (around the slack period) or 0 if there is accretion or erosion, respectively, over the time period considered (Eq. (2)).

$$
\Delta \mathrm{Z} \text { at a given location }=\sum_{\mathrm{j}=1}^{\mathrm{m}}\left\{\left(\alpha \frac{\mathrm{dS}_{\mathrm{Min}}}{\mathrm{dt}}-(1-\alpha) \frac{\mathrm{dE}}{\mathrm{dt}}\right) \Delta t\right\}
$$

We assumed that the deposition and erosion processes occur alternately, i.e., deposition taking place from the start of slack water periods until it reaches a certain critical current velocity. For the sake of simplicity, the rest of the tidal cycle is assumed to correspond to erosion. Thus, two time-series were defined to represent the depositional and erosional phases, based on the predetermined critical velocity for deposition. The sediment deposition rate $(\mathrm{m} / \mathrm{sec})$ can be represented in terms of settling velocity $\left(W_{s}\right)$, sediment concentration near the bed $\left(C_{b}\right)$, and bulk density of sediment (Prandle, 2009).

$\frac{\mathrm{dS}}{\mathrm{dt}}=\frac{\mathrm{W}_{\mathrm{s}} \mathrm{C}_{\mathrm{b}}}{\rho_{\mathrm{sed}}}$ 


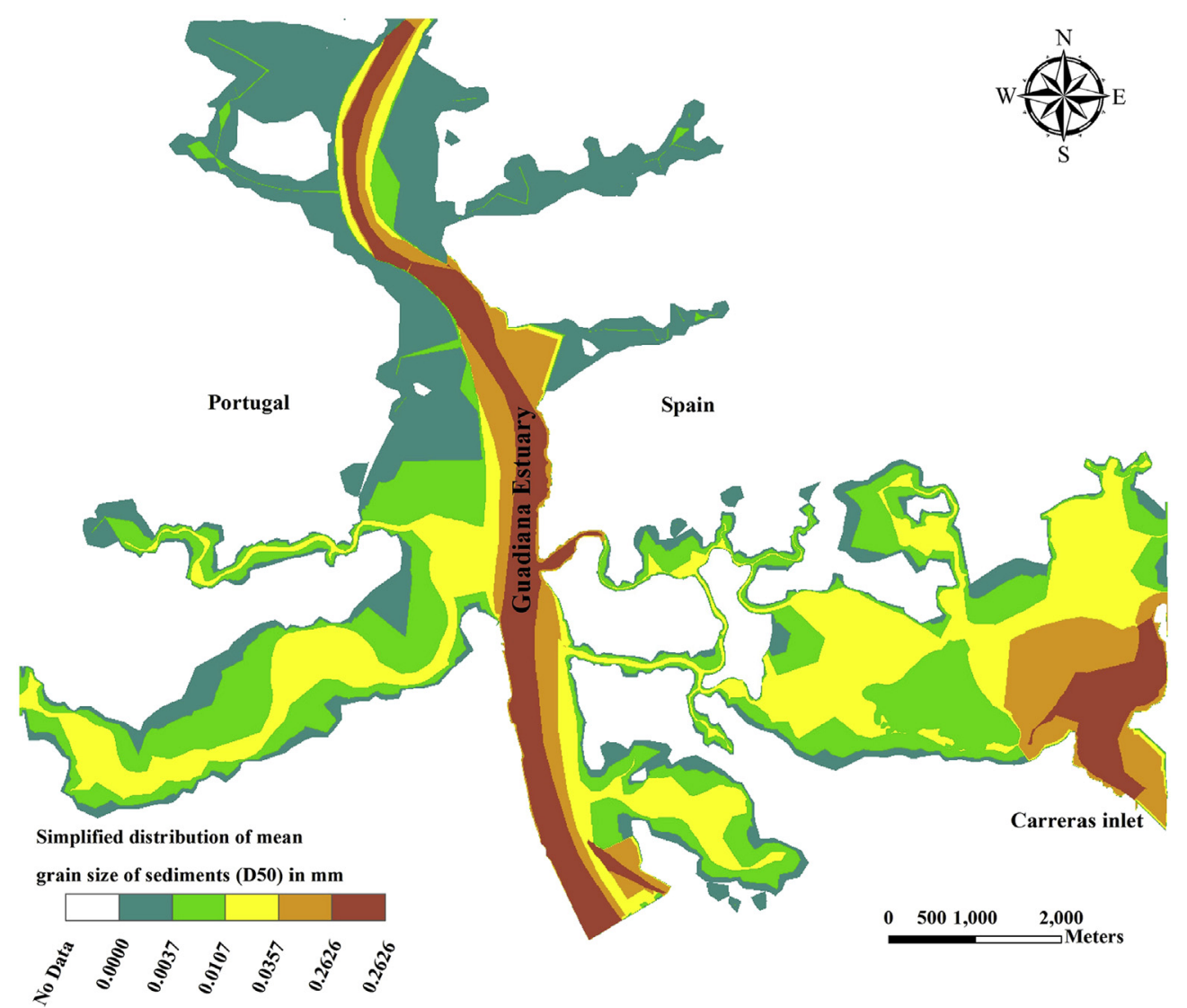

Fig. 3. The distribution of the sediment diameter $\left(D_{50}\right)$ in the Guadiana estuary system, based on the data of Boski et al. (2002, 2008) and Morales et al. (2006).

The settling velocity of fine-to-medium sand particles was estimated from average grain size diameter $\left(D_{50}\right)$ and the kinematic viscosity of water (Hallermeier, 1981). The settling velocity of very fine materials in the intertidal zone was estimated using the expression of Prandle (2009). $C_{b}$ can be related to average sediment concentration (Prandle, 2009). Morales (1995) proposed an empirical model for estimating the depth-averaged sediment concentration in the Guadiana Estuary in terms of river discharge $\mathrm{Q}_{\mathrm{R}}\left(\mathrm{m}^{3} / \mathrm{sec}\right)$.

$\overline{\mathrm{C}}=\left(\frac{\mathrm{Q}_{\mathrm{R}}}{0.03}\right)^{0.5}$

The short-term erosion rate in an estuary can be approximated using Prandle's (2004) simple formula, where $\gamma$ is the sediment erosion coefficient, $\mathrm{f}$ is the friction factor, $\rho_{\mathrm{w}}$ is the density of water, and $U_{t}$ is current velocity (Eq. (5)).

$\frac{\mathrm{dE}}{\mathrm{dt}}=\frac{\gamma f \rho_{\mathrm{w}\left(\mathrm{U}_{\mathrm{t}}\right)^{2}}}{\rho_{\mathrm{Sed}}}$

Current velocity was estimated using the set of solutions derived by Prandle (2004, 2009). We used the expression derived by Johns (1983) to estimate the bed friction in terms of bed roughness, which relates to the average sediment diameter at each cell of the bathymetry. The coefficient, $\gamma$, is given in Sampath et al. (2015). As in Stolper's (1996) estuarine sedimentation model, the long-term net accretion rate coefficients for each cell were derived as follows (Eq. (6)).
Long - term net accretion rate coefficient $=\frac{\left.\frac{\Delta S}{\Delta t}\right|_{\text {at a given location }}}{\left.\frac{\Delta S}{\Delta t}\right|_{\operatorname{Max}}}$

Thus, the long-term net accretion rate, at a given depth below the low-tide level, can be expressed in terms of representative sedimentation rate (scenario or observed value) (Fig. 4a) and the long-term net accretion rate coefficient (Eq. (7)).

$\frac{\Delta S_{\text {Net }}}{\Delta \mathrm{T}}=\mathrm{S}^{\operatorname{Rep}}\left(\frac{\left.\frac{\Delta \mathrm{S}}{\Delta \mathrm{t}}\right|_{\text {at a given location }}}{\left.\frac{\Delta S}{\Delta \mathrm{t}}\right|_{\operatorname{Max}}}\right)$

The recent sea-level change trend along the Portuguese continental margin was attributed to global causes (Dias and Taborda, 1992). Therefore, the decadal-timescale forecasting of morphological evolution for different river discharge functions was based on the updated IPCC (2007) projections of 5\%, and 95\% limit-time series of the A1FI SLR scenario (Fig. 4b). Hunter (2010) updated IPCC (2007) projections to include the influence of ice-sheet melting during this century.

Other physical parameters, including tidal constituents (Pinto, 2003) and SSC (Garel et al., 2009; Machado et al., 2007), were obtained from previous research. The theoretical framework of tidal propagation is based on the analytical solutions of the one- 

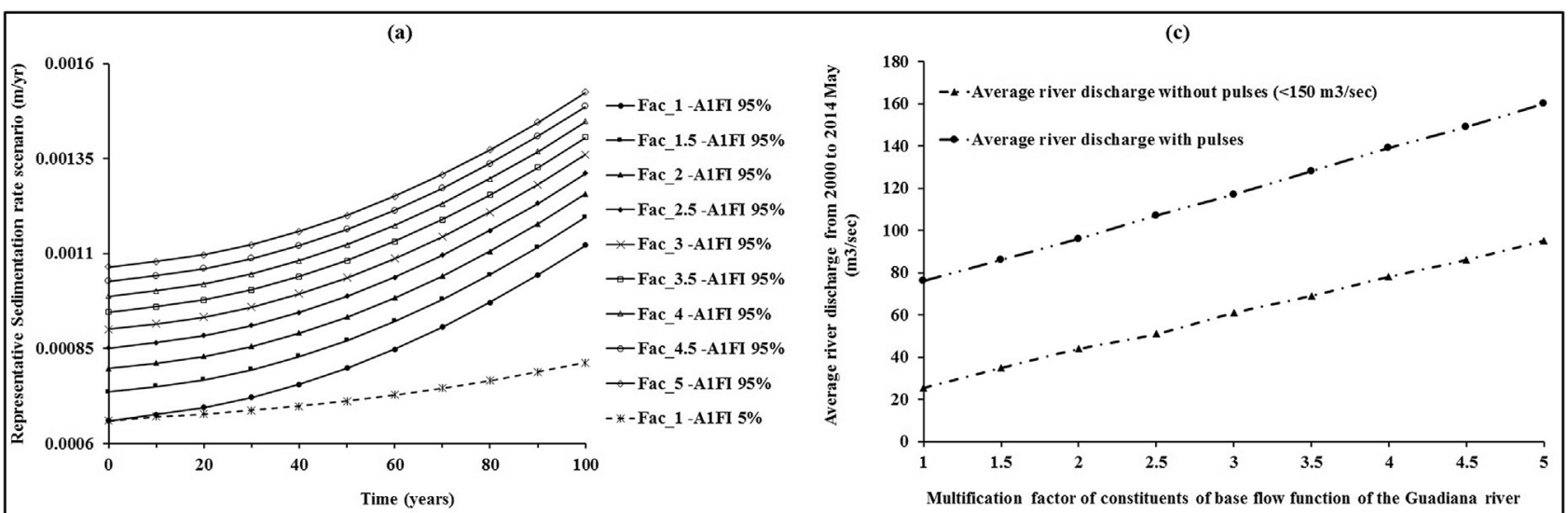

(b)
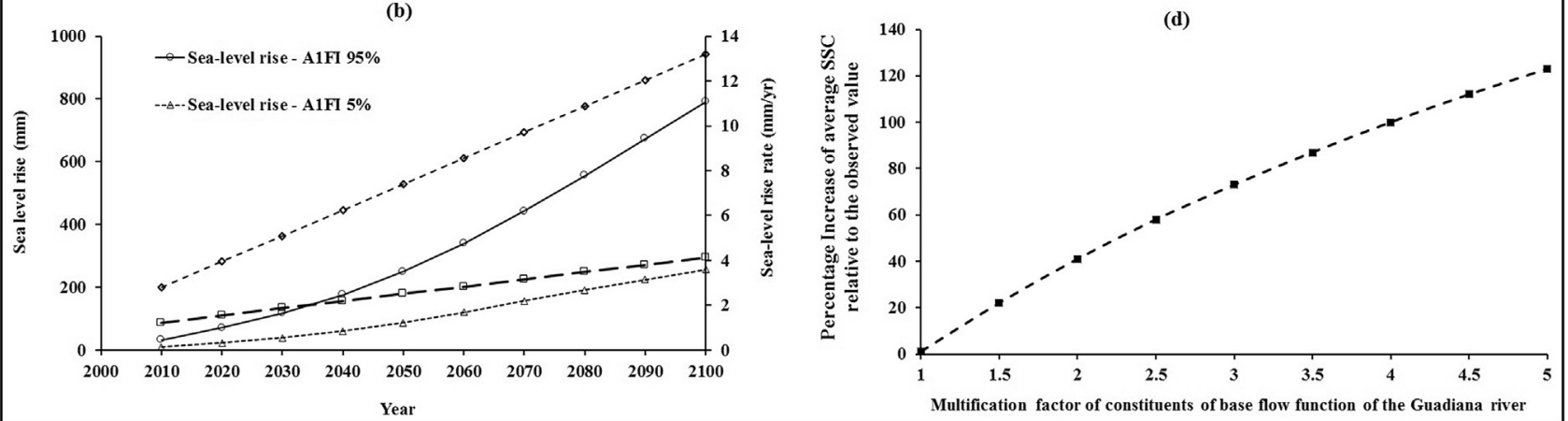

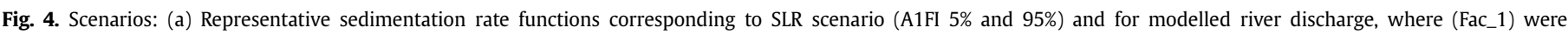

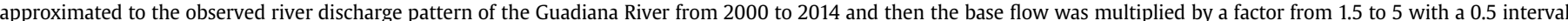

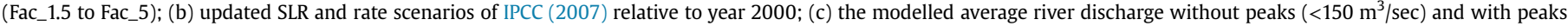
from 2000 to 2014 May; and (d) forecasted percentage increase of average SSC.

dimensional and cross-sectionally averaged shallow-water wave equations (Prandle, 2009). Equations were simplified for the firstorder tidal simulations by neglecting the convective terms and linearizing the quadratic friction terms and assuming triangularshaped synchronous estuaries (Prandle, 2003). The later assumption is considered for the Guadiana Estuary (Garel et al., 2009).

The river discharge time-series is based on observed river discharge at the Pulo do Lobo hydrological gauge station (Source: http://snirh.inag.pt/), which represents $91 \%$ of the Guadiana basin's runoff (Garel et al., 2009). The river discharge in the model consists of a base flow and pulses (Fig. 2b). The base flow represents the usual river discharge throughout the year, and pulses represent the instantaneous increase of river discharge due to heavy rain or dam flushing. The base flow of the Guadiana River discharge after the closure of the Alqueva Dam is approximated as a combination of trigonometric functions. Amplitudes of the trigonometric functions were $35,25,10$ and $8 \mathrm{~m}^{3} / \mathrm{sec}$. The observed average river discharge without peaks $\left(<150 \mathrm{~m}^{3} / \mathrm{sec}\right)$ from 2000 to 2014 (only up to May) is $22.4 \mathrm{~m}^{3} / \mathrm{sec}$, while it is $25.6 \mathrm{~m}^{3} / \mathrm{sec}$ using the trigonometric approximation. For sensitivity analysis, the amplitudes of the trigonometric functions of base flow were multiplied by a factor of $1.5-5$, with 0.5 intervals, while keeping the peaks from 2000 to 2014 . For each factor, the modelled average river discharge values with and without peaks from 2000 to 2014 are given in Fig. 4c. The percentage increase of the SSC is given in Fig. 4d. Spatial analysis was carried out using the ESRI ArcGIS software. The time-steps for hydrodynamic simulations were $20 \mathrm{~min}$, and long-term morphodynamic simulations were carried out with a 1-year time step.

\section{Results}

4.1. Translations of habitats in the Guadiana estuarine system due to $S L R$

In a situation of uninhibited supply of sediment from the catchment, as occurred during the Holocene period (Delgado et al., 2012), an increase of sedimentation rate should occur following the increase of accommodation space, created by SLR. But due to sediment starvation as a result of flow regulations (Factor 1 ), there would be a contrasting behaviours of sediment deposition/erosion in the intertidal zone area in response to the projected SLR of A1FI (both lower and upper limit scenarios). In the Portuguese and the Spanish margins, Fig. 5a and c indicate an insignificant increase of the intertidal zone area due to the lower limit scenarios. However, under the upper limit scenarios, the intertidal zone area increases slowly until 2050. Then rapid expansion of landward limits of the intertidal zone can be expected over the flat terrains above bank slopes (Fig. 5b and d). This behaviour is prominent on the Spanish margin, which governs the total behaviour (Fig. 5f).

The landward translation of intertidal zone boundaries may be observed mainly in areas associated with secondary channels on the Portuguese margin. On the Spanish margin, the submergence of the intertidal zone is mainly associated with areas where there is a complex tidal channel network. A significant transgression of mean sea level can be observed in the upper-reach bend of the main channel after 2050. The upper limit of A1FI SLR projection and sediment supply reduction result in a significant increase of erosion in the intertidal zone. This consequently results in an increased water depth throughout the estuary (Fig. 6). 


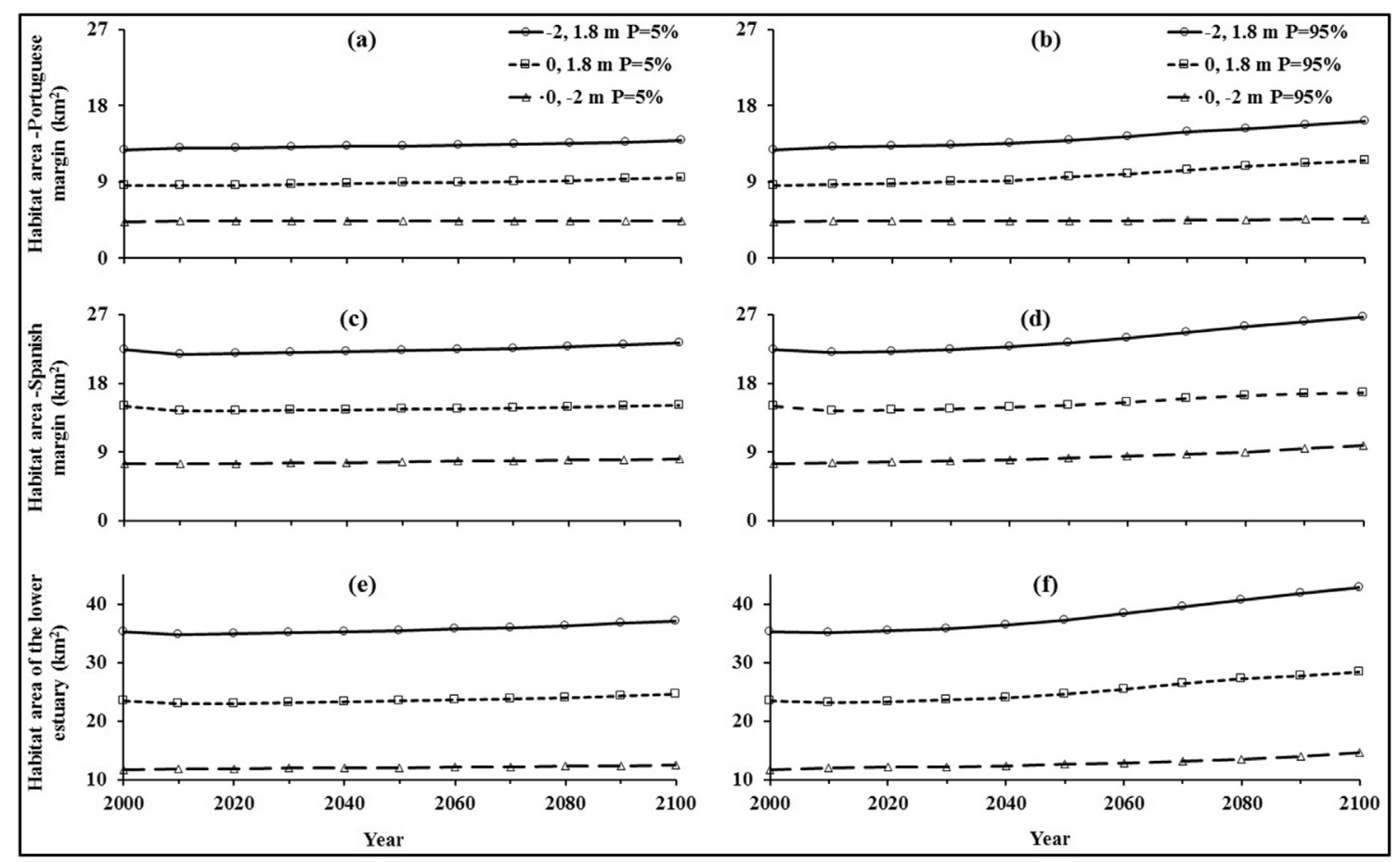

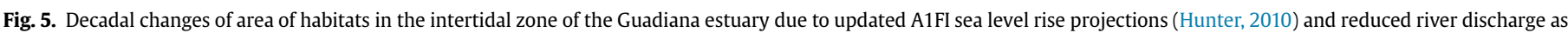
observed from 2000 to 2014 May (Factor 1): (a, c, and e) evolution due to lower limit scenarios ( $\mathrm{P}=5 \%$ ); and (b, d, and f) evolution due to upper limit scenarios ( $\mathrm{P}=95 \%$ ).

\subsection{Change in water depth due to SLR while base flow is increased}

The survival of the saltmarsh system facing SLR depends on its ability to compensate the increased water depth $(\Delta \mathrm{h})$ by increasing the sedimentation rate (Boski et al., 2015). The reduction of fluvial sediment supply will create an additional pressure on the functionality of the marsh system. If the present river flow pattern is maintained during this century (Factor 1 ), water depth in the intertidal zone would increase by up to $0.86 \mathrm{~m}$ (Fig. 7a). If base flow is multiplied by a factor of 1.5 (Fig. 7b) or 2 (Fig. 7c), the maximum water depth change in the intertidal zone will be $0.84 \mathrm{~m}$ and $0.82 \mathrm{~m}$, respectively. If the amplitude of the base flow function is multiplied by a factor 4 or more (impractical), a significant decrease in erosion in the intertidal zones can be expected (Fig. $7 \mathrm{~g}$, h, and i). That does not suggest the need of a dam bypassing mechanism for sediment to be delivered to the estuarine system to avoid deepening of saltmarsh platforms due to SLR.

\subsection{Decadal behaviour of the cumulative volume of sediment deposition and erosion}

Despite the base flow is being increased by applying a multiplication factor of $1.5-5$, there is a net erosion from the Guadiana estuarine system due to SLR and sediment supply reduction scenarios during the studied period (Fig. 8). For the same conditions, the net eroded sediment volume could be reduced by $25 \%$ and $40 \%$, respectively, with respect to the net eroded volume given by factor 1 (Table 2). Given that the Guadiana Estuary is at the terminal stage of the sediment infilling (Boski et al., 2008), and dominance of ebb currents (Garel and Ferreira, 2012), a net erosion of sediment can be expected due to SLR over this century.

The analysis of habitat translation due to the upper limit scenario of SLR and hypothetically increased base flow by a factor of 1.5 and 2 shows that the expansion of the intertidal zone areas is very similar to the expansion of area for factor 1 (Table 3 ). This is because the tidal influence is more dominant in determining intertidal zone expansion, resulting in $12 \mathrm{~km}^{2}$ of new tidal inundation compared to the hypothetical increase of fluvial sediment supply. In the worstcase SLR scenario, the entire existing low marshes will become mudflats while forcing all saltmarshes to translate into a new zones. Only a small part of high marsh will maintain the position observed in the year 2000. However, such migration of saltmarshes may actually occur if the properties of the new substratum are suitable for the successful translation of the halophytic habitats pushed by the SLR.

\section{Discussion}

\subsection{Implications of impacts due to SLR and river regulations}

There is conclusive evidence of accelerated SLR during this century (IPCC, 2014). Consequently, coastal managers and scientists are increasingly concerned about the future survival of saltmarshes (Kirwan et al., 2010). According to Mudd (2011), a morphological translation of marsh platforms to an elevation lower than mean high tide, either due to reduced sedimentation or an increased rate of SLR, will cause the demise of the halophytic marsh flora. According to Kirwan et al. (2010), availability of fluvial sediment is the critical factor in determining the health of a saltmarsh ecosystem. If these two conditions are superimposed, the vulnerability of the saltmarshes is very high, which would most likely be the case in the Guadiana estuarine system. The feedback effect (not considered in this study) of vanishing marsh systems increases erosion of barren sediment surfaces (Fagherazzi et al., 2006) leading to accelerated coastal erosion.

The holistic approach of estimating EF requirements is a process that allows scientists from many disciplines to integrate data and knowledge derived using methods of their choice to develop an understanding of flow-ecosystem relationships. These scientists then work with the other team members, within the 


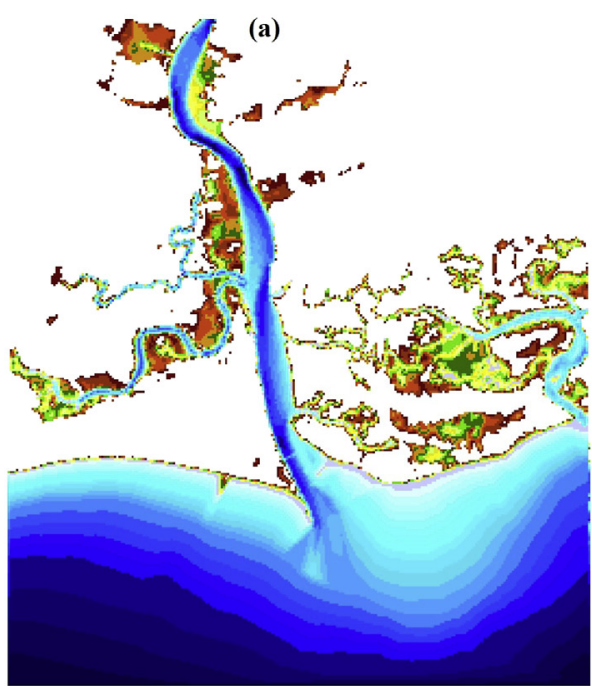

(c)

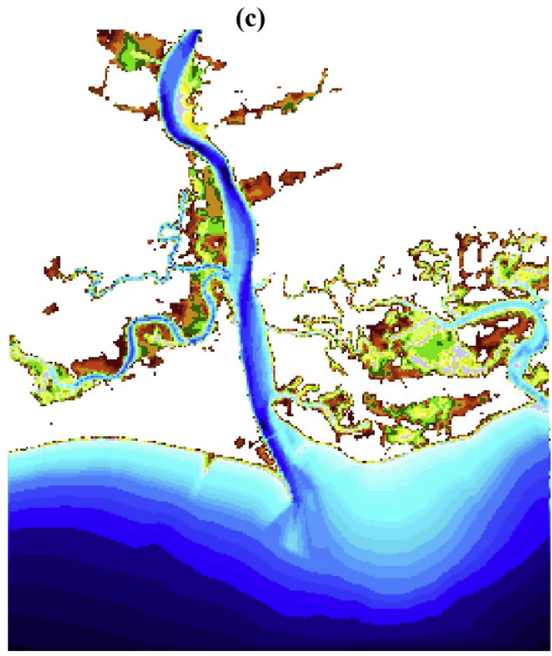

(e)

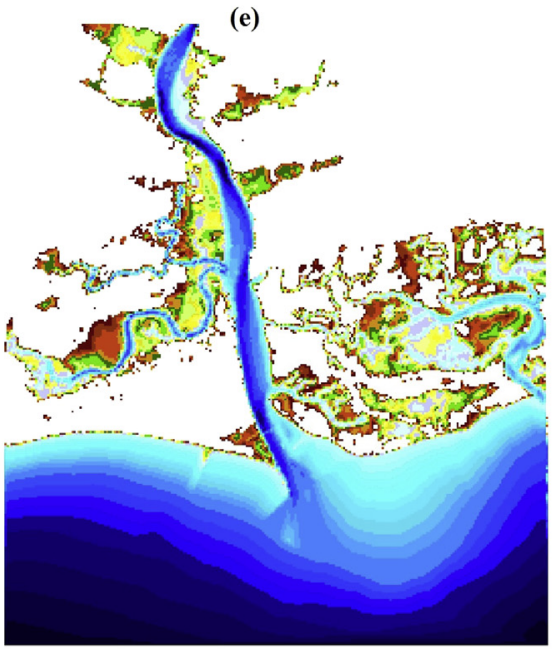

(b)

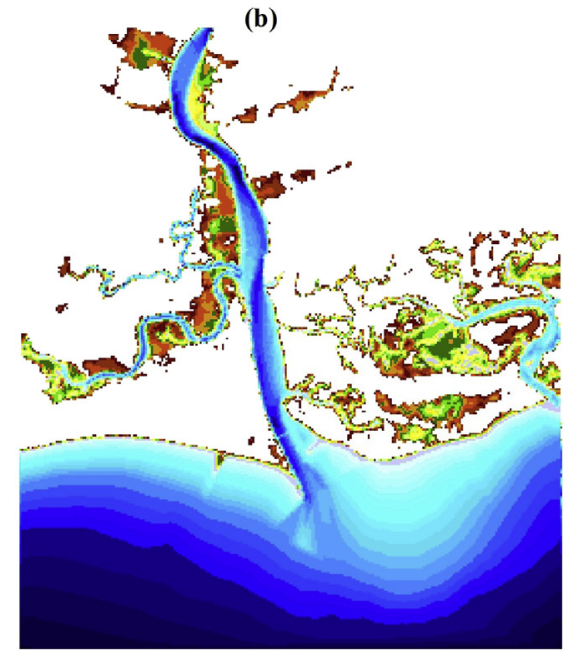

(d)

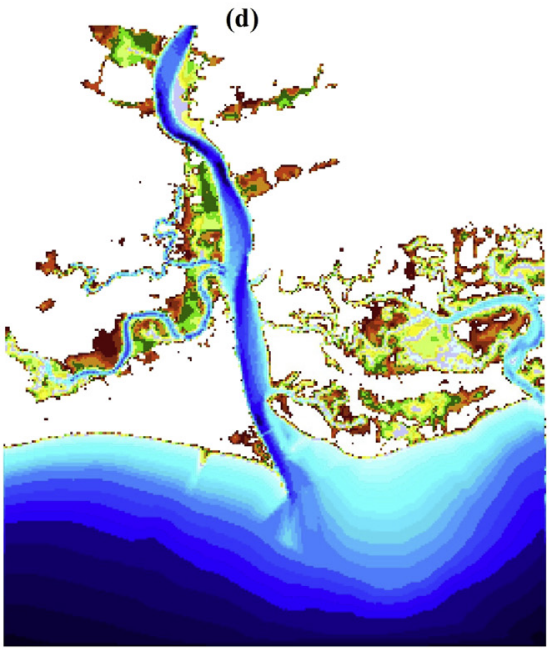

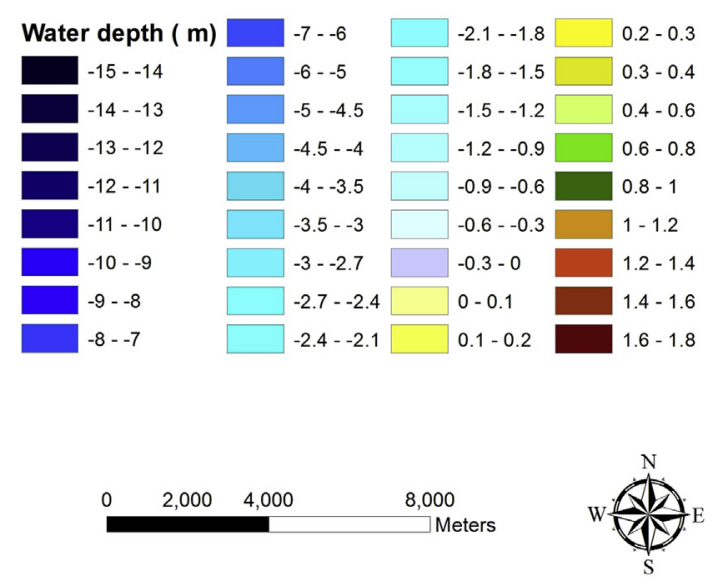

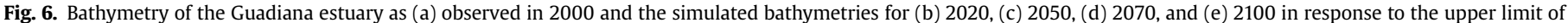
A1FI SLR scenario and modelled river discharge (Factor 1: equivalent to the observed river discharge pattern at the Pulo do Lobo gauge station).

overarching process of the holistic approach, to reach consensus on the magnitude and periodicity of EFs (King et al., 2003). For instance, a study by Chicharo et al. (2006) shows that a day discharge of $50 \mathrm{~m}^{3} / \mathrm{s}$, every week during dry periods, could be enough to avoid cyanobacteria blooms. When deciding EF requirements for the Guadiana River, negative impacts on nutrient 

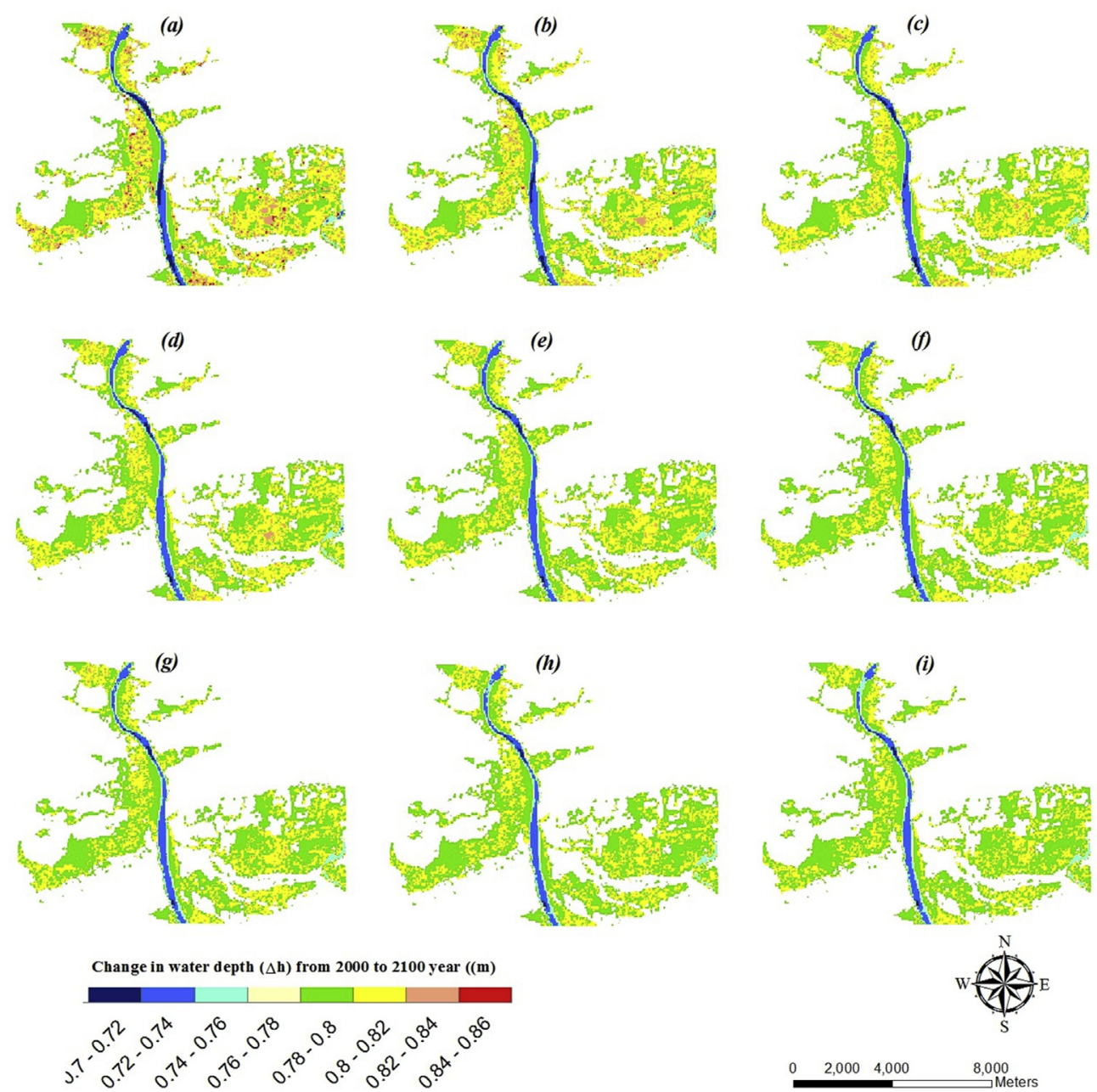

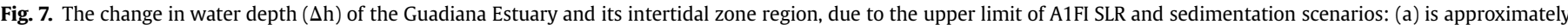

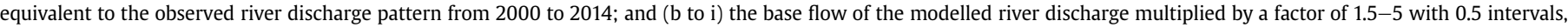
respectively.

biogeochemical cycles and productivity in the coastal zone due to reduced water supply during possible dry spells in an era of climate change have to be taken into account (Cravo et al., 2006). Similarly, the present study suggests that the estimation of EF in terms of simplified physical processes would be the first step to determine flow requirements to sustain saltmarshes.

If the fine sediment supply is reduced by significant human interference in the catchment, vegetation-sedimentation feedbacks can become limited, negatively affecting the accretion in saltmarshes (Kirwan and Temmerman, 2009). If natural translation of habitats are severely constrained by 'coastal squeeze' the present study indicates that saltmarshes are at an increasingly high risk of extinction due to SLR. Therefore, remedial measures should be adopted to minimize the effects of SLR and the reduction of fluvial sediment supply to the estuarine system. Holistic management of water resources in the Guadiana River catchment is a complex transboundary problem for Portugal and Spain (Galvão et al., 2012). Hence, a multi-dimensional and integrated approach has to be adopted to mitigate negative consequences on the estuarine ecosystems, including the saltmarsh habitats. As a first step, the EF of the river should be defined following a holistic approach (King et al., 2003). Since all major abiotic and biotic components are integral parts of the system to be managed, the full spectrum of flows, and their temporal and spatial variability should be taken into consideration. Aquatic scientists and engineers from many disciplines should use methods of their specific choice to develop an understanding of flow-ecosystem relationships, and then integrate new knowledge through a system-wide approach (King et al., 2003).

Plater and Kirby (2006) suggested that, under a scenario of reduced terrestrial sediment input (i.e., post-Alqueva Dam) and rapid SLR, the potential for back-barrier perimarine wetland development in the Guadiana estuary is greatly enhanced. Thus, the feasibility of developing perimarine wetlands at the interface of the sea and land has to be investigated using advanced cost-benefit analysis techniques. Moreover, as a part of managed realignment approach, an effective drainage system can be established as allowing the free tidal propagation does not automatically lead to the early reestablishment of the draining creek system (Boorman et al., 2002). Acceleration of the sedimentation rate can be enhanced by a number of techniques, like the so-called SchleswigHolstein method (Turner and Streever, 2002).

Managed realigned marsh systems may not have the same species richness as in natural systems (Mossman et al., 2012). Thus, transplanting of Spartina species may be a viable alternative to natural migration, despite difficulties when applied to relatively high-energy systems (Colenutt, 2001). Considering the inherent variation in natural saltmarshes and projected environmental 

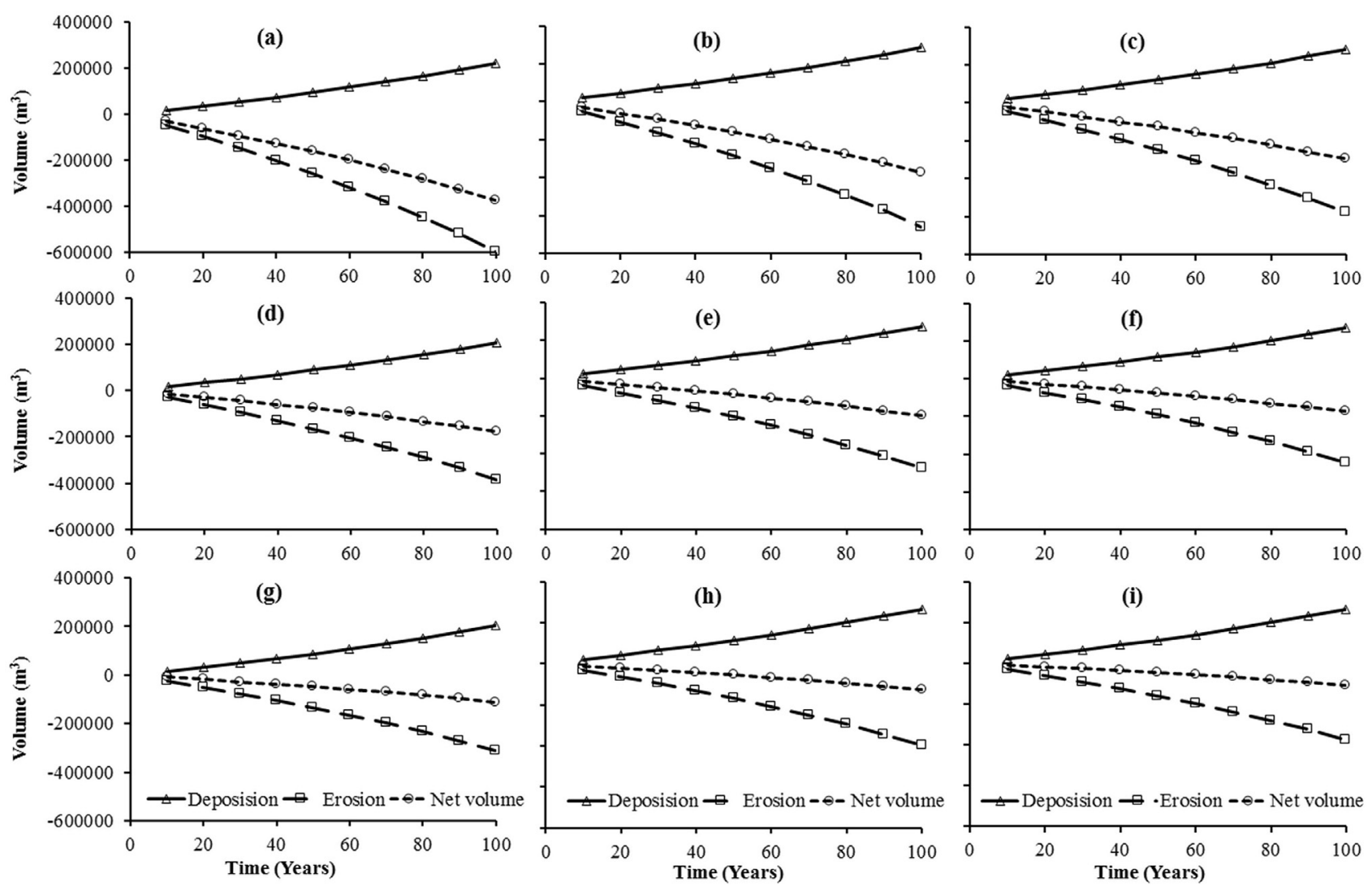

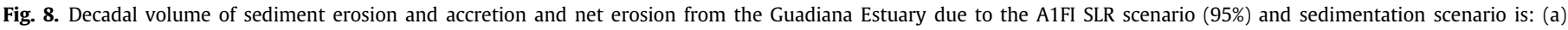

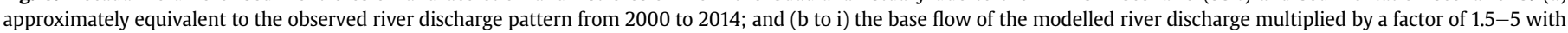
0.5 intervals, respectively.

Table 2

Net sedimentation rate over 100 years in response to increased base flow of the modelled river discharge by a factor of $1.5-5$ with 0.5 intervals, respectively.

\begin{tabular}{|c|c|c|}
\hline $\begin{array}{l}\text { Multiplication factor of the base flow rate of the } \\
\text { Guadiana river }(x)\end{array}$ & $\begin{array}{l}\text { Net erosion rate }\left(\mathrm{m}^{3 /} \mathrm{yr}\right) \text { at the end of the } \\
21 \text { st century } \\
\mathrm{Y}=1785 \ln (\mathrm{x})-3561\end{array}$ & $\begin{array}{l}\text { Percentage of reduction of net erosion volume rate compared to the } \\
\text { factor } 1 \text { (Observed) } \%\end{array}$ \\
\hline 1 (Observed) & 3749 & - \\
\hline 1.5 & 2780 & 25 \\
\hline 2 & 2223 & 40 \\
\hline 2.5 & 1787 & 52 \\
\hline 3 & 1497 & 60 \\
\hline 3.5 & 1303 & 65 \\
\hline 4 & 1114 & 70 \\
\hline 4.5 & 957 & 74 \\
\hline 5 & 811 & 78 \\
\hline
\end{tabular}

change, these additional management interventions of planting of marsh species, while manipulating topographic heterogeneity, can be applied to achieve at least the minimum levels of ecosystem functioning (Mossman et al., 2012).

\subsection{Limitations of the model}

Functioning of estuarine ecosystems, including saltmarshes, is determined by a complex interaction and feedback loops created by physical, biological, geological, and chemical processes, involving a number of important variables (Balls, 1994). However, for realistic predictions of their long-term fate, simplifications and generalizations of processes and inputs are unavoidable (De Vriend et al., 1993). For instance, the flocculation processes control the sedimentation of silt- and clay-sized sediments. Flocs have a lower settling velocity than individual particles of the same size, but a higher settling velocity than individual constituent particles (Christiansen et al., 2000). Such a process can enhance sedimentation in the intertidal zone. However, flocculation of fine sediment was not included in this model. For simplicity of the model, the sedimentation process was assumed to be defined by the limits associated with slack water periods. Such an assumption may be appropriate for the deposition of fine sediments with low settling velocities (Orme, 1990). Current velocity within saltmarshes decreases to zero during slack water periods (Allen, 2000) and it enhances the settlement of fine-grain sediment within the intertidal zone (Pratolongo et al., 2009).

In general, allochthonous (mineral) and autochthonous (organic) sedimentation and shallow compaction are dominant processes in saltmarsh areas. In the case of the Guadiana estuary, 
Table 3

Predicted areas of likely habitat types in the intertidal zone of the Guadiana Estuary due to upper-limits of SLR and sedimentation scenarios by the year 2100.

\begin{tabular}{|c|c|c|c|c|c|}
\hline \multirow[t]{4}{*}{ Habitat types (likely) } & \multirow[t]{4}{*}{ Area $-\mathrm{km}^{2}(2000)$} & \multirow[t]{4}{*}{ Occupied from the original habitat types of } & \multicolumn{3}{|c|}{$\begin{array}{l}\text { Area of likely habitats in margins by } 2100 \\
\left(\mathrm{~km}^{2}\right)\end{array}$} \\
\hline & & & \multirow{2}{*}{$\frac{\mathrm{A} 1 \mathrm{FI}}{(\mathrm{P}=95 \%)}$} & \multirow{2}{*}{$\frac{\mathrm{A} 1 \mathrm{FI}}{(\mathrm{P}=95 \%)}$} & \multirow{2}{*}{$\frac{\mathrm{A} 1 \mathrm{FI}}{(\mathrm{P}=95 \%)}$} \\
\hline & & & & & \\
\hline & & & Factor 1 & Factor 1.5 & Factor 2 \\
\hline \multirow[t]{5}{*}{ Mud flats $(-2-0 \mathrm{~m})$} & \multirow[t]{5}{*}{11.14} & Mud flat & 6.67 & 6.68 & 6.69 \\
\hline & & Low marsh & 4.16 & 4.16 & 4.16 \\
\hline & & Mid marsh & 3.52 & 3.48 & 3.45 \\
\hline & & Total & 14.35 & 14.32 & 14.3 \\
\hline & & Expansion (\%) & $(28.9)$ & (28.6) & (28.3) \\
\hline \multirow[t]{5}{*}{ Low-marsh $(0-0.5 \mathrm{~m})$} & \multirow[t]{5}{*}{4.16} & Low marsh & 0 & 0 & 0 \\
\hline & & Mid marsh & 2.51 & 2.55 & 2.58 \\
\hline & & High marsh & 4.59 & 4.54 & 4.50 \\
\hline & & Total & 7.10 & 7.09 & 7.08 \\
\hline & & Expansion (\%) & (70.9) & (70.5) & (70.2) \\
\hline \multirow[t]{4}{*}{ Mid-marsh $(0.5-1 \mathrm{~m})$} & \multirow[t]{4}{*}{6.03} & Mid marsh & 0 & 0 & 0 \\
\hline & & High marsh & 8.08 & 8.11 & 8.14 \\
\hline & & Total & 8.08 & 8.11 & 8.14 \\
\hline & & Expansion (\%) & (34.0) & (34.6) & (35.1) \\
\hline \multirow[t]{4}{*}{ High-marsh (1-1.8 m) } & \multirow[t]{4}{*}{13.98} & High marsh & 1.31 & 1.33 & 1.34 \\
\hline & & Newly inundated land & 11.98 & 11.98 & 11.98 \\
\hline & & Total & 13.29 & 13.31 & 13.32 \\
\hline & & Expansion (\%) & $(-4.9)$ & $(-4.7)$ & $(-4.7)$ \\
\hline \multirow[t]{4}{*}{ Intertidal zone (Total) $(-2-1.8 \mathrm{~m})$} & \multirow[t]{4}{*}{35.31} & Existing intertidal zone & 30.84 & 30.85 & 30.86 \\
\hline & & Newly inundated land & 11.98 & 11.98 & 11.98 \\
\hline & & Total & 42.82 & 42.83 & 42.84 \\
\hline & & Expansion (\%) & (21.26) & (21.3) & (21.32) \\
\hline
\end{tabular}

however, organic sediment deposition and auto compaction are also insignificant for long-term simulation of the morphological evolution (Sampath et al., 2015). This is due to intensive anaerobic respiration related to sulphate reduction that prevents the in situ preservation of organic material significantly (Boski et al., 2008). Due to the lack of peat layers and low content of organic carbon (Gonzalez Vila et al., 2003), compressibility of the sediments is limited (Santos and Boski, 2000). Moreover, shallow compaction in the Guadiana estuary can be neglected because of the increased supply of coarse sand into the estuary due to marine dominance during the 21st century. Highly regulated rivers can become marine-dominated with rapid SLR. As the estuary always try to maintain an equilibrium volume, they will start importing sediment from offshore regions (Ranasinghe et al., 2013). This will result in coarsening of sediment. Such conditions may force the saltmarsh to evolve differently. Similarly, if it is possible to establish a back-barrier perimarine wetland-as Plater and Kirby (2006) suggested that rapid SLR and reduced sediment supply are suitable for such developments-there would be an enhancement of biological productivity of the marsh systems leading to a different response. In this context, the present model can be viewed as a simple tool for preliminary estimation of the EF within the holistic approach, to reach consensus on river water discharge from the Alqueva Dam (King et al., 2003).

\subsection{Possible improvements to the approach}

This simple model can be further improved by integrating biogeochemical, demographic and ecohydrological models (e.g., Simas et al., 2001; Wolanski et al., 2006) with the present morphological model to include changes to the physical and biological settings due to reduced water supply. As suggested by Chicharo et al. (2006), further studies may be required to understand the relationships between the spectrum of EF, including its periodicity and magnitude of inflow pulse events and the estuarine ecosystem structure for developing a holistic management tool for the entire ecosystem. Settling of sediment by means of flocculation can be incorporated in an improved model by establishing the relationship between settling velocity and floc diameter (Sternberg et al., 1999). Furthermore, grain-size distribution has to be decomposed into three components: sediment that settled as flocs; sediment that settled as single grains; and, if present, sediment that has been remobilized after initial deposition (Christiansen et al., 2000). The later component may not have a significant influence for long-term simulation of marsh platform evolution caused by high wave attenuation over vegetation canopy in marsh environments. Wave heights and secondary currents within the Guadiana estuary are almost insignificant due to the sheltered nature of the area (Boski et al., 2008).

\section{Conclusions and recommendations}

The present study focuses on assessing the sensitivity of the base flow of the Guadiana River on morphological evolution in the estuary and saltmarshes in response to projected SLR and reduced sediment supply due to strong flow regulations by a large number of dams constructed over the past 50 years. Simulations were carried out for ten cases: (i and ii) base flow approximately equivalent to the observed base flow component of the Guadiana River and both 5\% and 95\% limit time-series of the A1FI SLR scenario; and (iii to $\mathrm{x}$ ) amplitudes of base flow function were multiplied by a factor of 1.5-5, with 0.5 intervals and only 95\% limit time-series of the A1FI SLR scenario. The assessment was based on a set of analytical solutions to simplified equations of tidal wave motion in synchronous estuaries and empirical knowledge of the study area.

According to the results, saltmarsh habitats may not be affected severely in response to lower-limit SLR and sedimentation scenarios. Even under upper-limit scenarios, a similar situation can be expected until 2050 and then rapid submergence over flat terrains beyond the bank slopes. However, the expansion of areas under tidal inundation and rising sea levels as per the upper limit scenarios is very prominent near secondary channels on the 
Portuguese margin. The expansion of intertidal zone limits on the Spanish margin is visible adjacent to the secondary tidal channels of the Carreras Inlet. A significant increase of the mud-flat area is a concern due to its low biodiversity. Under the worst sea-level rise scenario, low, mid and marshes could migrate into a new upwards setting, if the biogeochemical conditions for halophytic plant development are appropriate and there are no anthropogenic physical constraints. The available area for high saltmarshes will shrink when compared to the situation observed in the year 2000. A simple increase of base flow is not sufficient to overcome the risks of habitat extinction and this points to the deficiencies of defining the EF as a percentage of dry season flow.

Despite the simplicity of the model, its application to the Guadiana estuarine system leads to the understanding that drowning of saltmarshes due to SLR and sediment starvation has to be managed by implementing a multi-dimensional and integrated approach that may consist of: (1) Determination of EF based on a full spectrum of natural flows, in terms of temporal and spatial variability (holistic approach); (2) Bypassing dams to allow the fine fluvial sediment needed to sustain the marshes to be delivered to the estuarine system; (3) Managed realignment to enhance the natural sedimentation within the system; and (4) Possible transplanting of saltmarsh species or development of back-barrier perimarine wetlands.

\section{Acknowledgments}

The first author acknowledges FCT (SFRH/BD/70747/2010) and the CIMA - Centro de Investigação Marinha e Ambiental, Universidade do Algarve (UID/MAR/00350/2013) for granting scholarships to carry out this work as part of his PhD research. The comments of two anonymous reviewers and the Editor, have helped to significantly improve an earlier version of the manuscript. The graphical abstract was drawn using some of the symbols given in the "Integration and Application Network", an initiative of the University of Maryland Center for Environmental Science.

\section{References}

Allen, J.R.L., 1995. Salt marsh growth and Flandrian sea level: implication of simulation model for Flandrian coastal stratigraphy and peat-based sea-level curves. Sediment. Geol. 100, 21-45.

Allen, J.R.L., 2000. Morphodynamics of Holocene salt marshes: a review sketch from the Atlantic and southern North sea coasts of Europe. Quat. Sci. Rev. 19 1155-1231.

Arthington, A.H., Bunn, S.E., Poff, L.N., Naiman, R.J., 2006. The challenge of providing environmental flow rules to sustain river ecosystems. Ecol. Appl. 16, 1311-1318.

Balls, P.W., 1994. Nutrient inputs to estuaries from nine Scottish east coast rivers: influence of estuarine processes on inputs to the North sea. Estuar. Coast. Shelf Sci. 39, 329-352.

Boorman, L., Hazelden, J., Boorman, M., 2002. New Salt Marshes for Old - Salt Marsh Creation and Management. Littoral 2002. The Changing Coast. EUROCOAST EUCC, Porto - Portugal Ed. EUROCOAST, Portugal, pp. 35-45.

Boski, T., Moura, D., Veiga-Pires, C., Camacho, S., Duarte, D., Scott, D.B., Fernandes, S.G., 2002. Postglacial sea-level rise and sedimentary response in the Guadiana Estuary, Portugal/Spain border. Sediment. Geol. 150, 103-122.

Boski, T., Camacho, S., Moura, D., Fletcher, W., Wilamowski, A., Veiga-Pires, C., Correia, V., Loureiro, C., Santana, P., 2008. Chronology of the sedimentary processes during the postglacial sea level rise in two estuaries of the Algarve coast, Southern Portugal. Estuar. Coast. Shelf Sci. 77, 230-244.

Boski, T., Bezerra, F.H.R., Pereira, L.F., Souza, A.M., Maia, R.P., Lima-Filho, F.P., 2015 Sea-level rise since $8.2 \mathrm{ka}$ recorded in the sediments of the Potengi-Jundiai estuary, NE brasil. Mar. Geol. 365, 1-13.

Caetano, M., Vale, C., Falcão, M., 2006. Particulate metal distribution in Guadiana estuary punctuated by flood episodes. Estuar. Coast. Shelf Sci. 70, 109-116.

Chicharo, L., Chicharo, M.A., Ben-Hamadou, R., 2006. Use of a hydrotechnica infrastructure (Alqueva Dam) to regulate planktonic assemblages in the Guadiana estuary: basis for sustainable water and ecosystem services management. Estuar. Coast. Shelf Sci. 70, 3-18.

Chícharo, L., Ben Hamadou, R., Amaral, A., Range, P., Mateus, C., Piló, D., Marques, R. 2009. Application and demonstration of the Ecohydrology approach for the sustainable functioning of the Guadiana estuary (South Portugal). Ecohydrol. Hidrobiology 9 (1), 55-71.
Christiansen, T., Wiberg, P.L., Milligan, T.G., 2000. Flow and sediment transport on a tidal salt marsh surface. Estuar. Coast. Shelf Sci. 50, 315-331.

Colenutt, A., 2001. Saltmarsh Management Techniques: A Review. New Forest District Council, Coast Protection Group, UK, 29 pp.

Cravo, A., Madureira, M., Felicia, H., Rita, F., Bebianno, M.J., 2006. Impact of outflow from the Guadiana River on the distribution of suspended particulate matter and nutrients in the adjacent coastal zone. Estuar. Coast. Shelf Sci. 70, 63-75.

Day, J.W., Shaffer, G.P., Britsch, L.D., Reed, D.J., Hawes, S.R., Cahoon, D., 2000. Pattern and process of land loss in the Mississippi Delta: a spatial and temporal analysis of wetland habitat change. Estuaries 23, 425-438.

De Vriend, H.J., Capobianco, M., Chesher, T., de Swart, H.E., Latteux, B., Stive, M.J.F., 1993. Approaches to long-term modelling of coastal morphology: a review. Coast. Eng. 21, 225-269.

Delgado, J., Boski, T., Nieto, J.M., Pereira, L., Moura, D., Gomes, A., Sousa, C., GarcíaTenorio, R., 2012. Sea-level rise and anthropogenic activities recorded in the late Pleistocene/Holocene sedimentary infill of the Guadiana Estuary (SW Iberia). Quat. Sci. Rev. 33, 121-141.

Dias, J.M.A., Taborda, R., 1992. Tidal gauge data in deducing secular trends of relative sea-level and crustal movements in Portugal. J. Coast. Res. 8 (3), 655-659.

Dias, J.M.A., Gonzalez, R., Ferreira, Ó., 2004. Natural Versus Anthropic Causes in Variations of Sand Export from River Basins: an Example from the Guadiana River Mouth (Southwestern Iberia). Rapid Transgression into Semi-enclosed Basins. Polish Geological Institute Special Papers, Gdansk, pp. 95-102.

Dijkema, K.S., 1987. Geography of the salt marshes in Europe. Z. für Geomorphol. 31, 489-499.

Fagherazzi, S., Carniello, L., D'Alpaos, L., Defina, A., 2006. Critical bifurcation of shallow microtidal landforms in tidal flats and salt marshes. Proc. Natl. Acad. Sci. U. S. A. 103, 8337-8341.

Faria, A., Morais, P., Chicharo, M.A., 2006. Ichthyoplankton dynamics in the Guadiana estuary and adjacent coastal area, South-East Portugal. Estuar. Coast. Shelf Sci. 70, 85-97.

Fortunato, A.B., Oliveira, A., 2004. A modeling system for tidally driven long-term morphodynamics. J. Hydraulic Res. 42, 426-434.

Fortunato, A.B., Pinto, L., Oliveira, A., Ferreira, J.S., 2002. Tidally generated shelf waves off the western Iberian coast. Cont. Shelf Res. 22, 1935-1950.

French, J., 2006. Tidal marsh sedimentation and resilience to environmental change: exploratory modelling of tidal, sea-level and sediment supply forcing in predominantly allochthonous systems. Mar. Geol. 235, 119-136.

Galvão, H.M., Reis, M.P., Domingues, R.B., Caetano, S.M., Mesquita, S., Barbosa, A.B., Costa, C., Vilchez, C., Teixeira, M.R., 2012. Ecological tools for the management of cyanobacteria blooms in the Guadiana River watershed, southwest Iberia. In: Kumarasamy, M. (Ed.), Studies on Water Management Issues. InTech, 174 pp.

Garel, E., Ferreira, Ó., 2012. Fortnightly changes in water transport direction across the mouth of a narrow estuary. Estuaries Coasts 36, 286-299.

Garel, E., Pinto, L., Santos, A., Ferreira, Ó., 2009. Tidal and river discharge forcing upon water and sediment circulation at a rockbound estuary (Guadiana estuary, Portugal). Estuar. Coast. Shelf Sci. 84, 269-281.

Gonzalez, R., Dias, J.A., Lobo, F., Mendes, I., Plaza, F., 2004. Sedimentological and paleoenvironmental characterisation of transgressive sediments on the Guadiana shelf Northern Gulf of Cadiz, SW Iberia. Quat. Int. 120, 133e144.

Gonzalez Vila, F.J., Polvillo, O., Boski, T., Moura, M.D., Andrés, J.R., 2003. A biomarker approach to the organic matter deposited in coastal estuarine sediments during Holocene: a case study in the Guadiana River estuary. Org. Geochem. 34, $1601-1613$.

Gopal, B., 2013. Methodologies for the assessment of environmental flows. In: Gopal, B. (Ed.), Environmental Flow. National Institute of Ecology, India, pp. 129-182.

Hallermeier, R.J., 1981. Terminal velocity of commonly occurring sand grains. Sedimentology 28, 859-865.

Hunter, J.R., 2010. Estimating sea-level extremes under conditions of uncertain sealevel rise. Clim. Change 99, 331-350.

IPCC, 2007. Climate change 2007: the physical science basis. In: Solomon, S., Oin, D., Manning, M., Chen, Z., Marquis, M., Averyt, K.B., Tignor, M., Miller, H.L. (Eds.), Contribution of Working Group I to the Fourth Assessment Report of the Intergovernmental Panel on Climate Change. Cambridge University Press, Cambridge, United Kingdom and New York, NY, USA.

IPCC, 2014. In: Core Writing Team, Pachauri, R.K., Meyer, L.A. (Eds.), Climate Change 2014: Synthesis Report. A Contribution of Working Groups I, II, and III to the Fifth Assessment Report of the Intergovernmental Panel on Climate Change. IPCC, Geneva, Switzerland, 151 pp.

Johns, B., 1983. Turbulence modelling beneath waves over beaches. In: Johns, B. (Ed.), Physical Oceanography of Coastal and Shelf Seas, 35. Elsevier Oceanography Series, pp. 111-133.

King, J., Brown, C., Sabet, H., 2003. A scenario-based holistic approach to environmental flow assessments for rivers. River Res. Appl. 19, 619-639.

Kirwan, M., Temmerman, S., 2009. Coastal marsh response to historical and future sea-level acceleration. Quat. Sci. Rev. 28, 1801-1808.

Kirwan, M.L., Guntenspergen, G.R., D'Alpaos, A., Morris, J.T., Mudd, S.M., Temmerman, S., 2010. Limits on the adaptability of coastal marshes to rising sea level. Geophys. Res. Lett. 37, L23401.

Lobo, J., Plaza, F., Gonzá les, R., Dias, J., Kapsimalis, V., Mendes, I., Rio, V.D., 2004. Estimations of bedload sediment transport in the Guadiana estuary (SW Iberian Peninsula) during low river discharge periods. J. Coast. Res. 41 (Special Issue), $12-26$.

Lobo, F.J., Dias, J.M.A., González, R., Hernández-Molina, F.J., Morales, J.A., Díaz del 
Río, V., 2003. High-resolution seismic stratigraphy of a narrow, bedrockcontrolled estuary: the Guadiana estuarine system, SW Iberia. J. Sediment. Res. 73, 973-986.

Machado, A., Rocha, F., Gomes, C., Dias, J., 2007. Distribution and composition of suspended particulate matter in Guadiana estuary (southwestern Iberian Peninsula). J. Coast. Res. 50, 1040-1045.

Mateus, M., Mateus, S., Baretta, J.W., 2008. Basic concepts of estuarine ecology. In: Neves, R., Baretta, J.W., Mateus, M. (Eds.), Perspectives of Integrated Coastal Zone Management in South America. IST press, pp. 3-14.

Möller, I., Spencer, T., 2002. Wave dissipation over macro-tidal saltmarshes: effects of marsh edge typology and vegetation change. J. Coast. Res. SI 36, 506-521.

Morales, J.A., 1995. Sedimentologia del estuario del Rio Guadiana (S.W. Espanã-Portugal). Servicio de Publicaciones, Huelva University, 322 pp.

Morales, J.A., 1997. Evolution and facies architecture of the mesotidal Guadiana River delta (S.W. Spain-Portugal). Mar. Geol. 138, 127-148.

Morales, J.A., Delgado, I., Gutierrez-Mas, J.M., 2006. Sedimentary characterization of bed types along the Guadiana Estuary (SW Europe) before the construction of the Alqueva dam. Estuar. Coast. Shelf Sci. 70, 117-131.

Morales, J.A., Sedrati, M., Cantano, M., Ramírez, A.R., Delgado, I., Lozano, C., FlorBlanco, G., 2014. From the continent to the coast: the bedload transport across the lower sector of the Guadiana River Mouth (Spain-Portugal). Géomorphologie Relief, Process. Environ. 3, 55-64.

Mossman, H.L., Davy, A.J., Grant, A., 2012. Does managed coastal realignment create saltmarshes with 'equivalent biological characteristics' to natural reference sites? J. Appl. Ecol. 49, 1446-1456.

Mudd, S.M., 2011. The life and death of salt marshes in response to anthropogenic disturbance of sediment supply. Geology 39, 511-512.

Orme, A.R., 1990. Wetland morphology, hydrodynamics and sedimentation. In: Williams, M. (Ed.), Wetlands: A Threatened Landscape. Basil Blackwell, Oxford, pp. 42-94.

Paolo, F.S., Fricker, H.A., Padman, L. 2015. Volume loss from Antarctic ice shelves is accelerating. Science 6232, 327-331.

Pinto, L., 2003. Estrataficação salina no Estuário do Guadiana. Master thesis. Faculdade de Ciências da Universidade de Lisboa, Lisboa, 179 pp.

Plater, A., Kirby, J., 2006. The potential for perimarine wetlands as an ecohydrological and phytotechnological management tool in the Guadiana estuary, Portugal. Estuar. Coast. Shelf Sci. 70, 98-108.

Portela, L., 2006. Sediment delivery from the Guadiana estuary to the coastal ocean. J. Coast. Res. 1819-1823. Special Issue No. 39.

Prandle, D., 2003. Relationships between tidal dynamics and bathymetry in strongly convergent estuaries. Journal of Physical. Oceanography 33 (12), 2738-2750.

Prandle, D., 2004. How tides and river flow determine estuarine bathymetry. Progress in. Oceanography 61 (1), 1-26.
Prandle, D., 2009. Estuaries: Dynamics, Mixing, Sedimentation and Morphology Cambridge University Press, Cambridge, UK, 235 pp.

Pratolongo, P.D., Kirby, J.R., Plater, A., Brinson, M.M., 2009. Temperate coastal wetlands: morphology, sediment processes, and plant communities. In: Perillo, G.M.E., et al. (Eds.), Coastal Wetlands: an Integrated Ecosystem Approach, pp. 89-118.

Ranasinghe, R., Duong, T.M., Uhlenbrook, S., Roelvink, D., Stive, M.J.F., 2013. Climatechange impact assessment for inlet- interrupted coastlines. Nat. Clim. Change 3 83-87.

Sampath, D.M.R., 2016. Coastal Responses to Sea-level Rise on Centennial to Millennial Time Scales: Development of a Hybrid Model-based Forecasting for the Guadiana Estuary. PhD thesis. 303 pp.

Sampath, D.M.R. Boski, T., Loureiro, C., Sousa, C., 2015. Modelling of estuarine response to sea-level rise during the Holocene: application to the Guadiana Estuary-SW Iberia. Geomorphology 232, 47-64.

Santos, A., Boski, T., 2000. The comparison of Holocene sedimentary infill in the two areas of contrasted sedimentary dynamic of Guadiana Estuary. In: Carvalho, S.G., Gomes, V.M. (Eds.), Os Estua'rios de Portugal e os Planos de Bacia Hidrogra'fica. Associaç ao Eurocoast, Lisbon, pp. 53-64.

Seo, Ki-Weon, Waliser D.E. Lee Choon-Ki, Tian, Baijun, Scambos, T, Kim, Baek-Min, Angelen, J.H., Van den Broeke, M.R., 2015. Accelerated mass loss from Greenland ice sheet: links to atmospheric circulation in the North Atlantic. Glob. Planet. Change 128, 61-71.

Simas, T., Nunes, J.P., Ferreira, J.G., 2001. Effects of global climate change on coastal salt marshes. Ecol. Model. 139, 1-15.

Sternberg, R., Berhane, I., Ogston, A., 1999. Measurement of size and settling velocity of suspended aggregates on the Northern California continental shelf. Mar. Geol. 154, 43-53.

Stolper, D., 1996. The Impact of Sea-level Rise on Estuarine Mangroves: Development and Application of a Simulation Model. Honours Thesis. University of Sydney, Sydney, $90 \mathrm{pp}$.

Tharme, R.E., 2003. A global perspective on environmental flow assessment: emerging trends in the development and application of environmental flow methodologies for rivers. River Res. Appl. 19, 397-441.

Turner, R.E., Streever, B., 2002. Approaches to Coastal Wetland Restoration: Northern Gulf of Mexico. SPB Academic Publishing, The Hague, 151pp.

Veiga, P. Vieira, L., Bexiga, C., Sã, R., Erzini, K., 2006. Structure and temporal variations of fish assemblages of the Castro Marim salt marsh, southern Portugal. Estuar. Coast. Shelf Sci. 70, 27-38.

Wolanski, E., Chicharo, L., Chicharo, M.A., Morais, P., 2006. An ecohydrology mode of the Guadiana estuary (South Portugal). Estuarine. Coast. Shelf Sci. 70, 132-143. 